\author{
Miron Wolny \\ (Olsztyn) \\ https://orcid.org/0000-0001-7835-128X
}

\title{
DZIEJE HANNIBALA - LITERATURA ANTYCZNA A MALARSKIE WYOBRAŻENIA
}

\begin{abstract}
The paper attempts to link Hannibal's history to selected paintings which sought to portray it. The vast majority of the analyzed painterly representations were created in times when critical studies of ancient literature had not yet developed, which naturally fostered uncritical approach towards the heroic deeds of Hannibal as described in literature. Such a situation promoted generalizations and often exaggeration of the presented events. The paintings had their specific addressees, who had to have prior grounding in order to be able to understand their symbolism, which was quite often complex. The author of this paper analyses the aspects of Hannibal's actions which were particularly attractive to European culture.
\end{abstract}

\section{Keywords}

Carthage, Hannibal, ancient literature, paintings, determination

Nullo labore aut corpus fatigari aut animus vinci poterat

Livius, Ab urbe condita libri, 21.4.5.

Rozległe malowidło naścienne, zdobiące wnętrze Muzeów Kapitolińskich, w jednej ze swoich odsłon przedstawia brodatego mężczyznę w turbanie, który podróżuje, siedząc na słoniu. Tematyka tego datowanego na rok 1505 dzieła odnosi się do znanego $\mathrm{z}$ historii starożytnej motywu - przekroczenia masywu górskiego przez kartagińskiego wodza Hannibala ${ }^{1}$. Realia epoki stają się tutaj sprawą zupeł-

\footnotetext{
${ }^{1}$ Sommella i Tittoni Monti 1996, s. 36.
} 
nie drugorzędną, bowiem Jacopo Ripanda rozmyślnie nawiązuje do wydarzeń, które znane były Europie z jej niedawnej historii, czyli wojen Franków z Saracenami i Turków z chrześcijanami. Dzieło Jacopo Ripandy wskazuje przeto, że atrakcyjne stawały się same motywy, a nie skrupulatne dążenie do odtworzenia prawdy historycznej. Operowanie zaczerpniętymi z antyku motywami, rozwijające się we wczesnym renesansie, zapełniało kulturowy krajobraz Europy tematyką w aluzyjny sposób nawiązującą do wydarzeń aktualnych i z różnych punktów widzenia mogących spełniać zadania natury moralizatorskiej.

Motyw wodza kartagińskiego Hannibala w szerokim wachlarzu zagadnień, klasyfikowanych jako recepcja antyku, stanowi przykład dość problematyczny. $\mathrm{Z}$ jednej strony Punijczyk staje się humanistycznym przykładem osoby posiadającej swoje ułomności, z drugiej zaś jego antyczne dossier jest tak dalece nacechowane negatywnymi ocenami ${ }^{2}$, że naturalną koleją rzeczy powstaje pytanie o źródła atrakcyjności tego motywu. Rozeznanie, jakie posiadamy na temat Hannibala dzięki literaturze antycznej, pomimo szeregu trudności metodologicznych, układa przed czytelnikiem koherentny obraz dziejów tej postaci. Przyszły wódz kartagiński, syn Hamilkara Barkasa, urodzony w starej kolonii fenickiej - Kartaginie w roku 247 p.n.e., miał być wychowany w duchu nienawiści do Rzymian, którym Punijczycy nie mogli wybaczyć barbarzyństwa pierwszej wojny punickiej (264241 p.n.e.) i jej skutków³. Hannibal, stojący na czele potężnej armii, inicjując drugą wojnę punicką (218-201 p.n.e.), miał wkroczyć do Italii najtrudniejszą z możliwych dróg, przeprawiając się przez Alpy, później zaś zadając Rzymianom dotkliwe klęski - nad Trebią (218 p.n.e.), Jeziorem Trazymeńskim (217 p.n.e.) i pod Kannami (216 p.n.e.), bliski był rozbicia federacji italskiej. Jego zuchwałe plany $\mathrm{w}$ polityce międzynarodowej nie znalazły ostatecznie odpowiedniego rezonansu wśród władców państw hellenistycznych, którzy wzorem Filipa V woleli z oddali obserwować konflikt ${ }^{5}$. Problematycznie przedstawiały się także stosunki w samej Kartaginie, co pozwala wnioskować, że nie wszyscy prominentni politycy czasów Hannibala podzielali entuzjazm dla wojny w Italii. Wyczerpana logistycznie armia dowodzona przez Hannibala musiała więc powrócić do Afryki Północnej, aby bronić swojej ojczyzny w defensywnym finale wojny, uwieńczonym przegraną dla Kartaginy bitwą pod Zamą (202 p.n.e.). Upokarzający pokój zawarty z Rzymianami (201 p.n.e.) przyćmił odległe zwycięstwa Hannibala, skazując go na polityczną walkę z nowymi ugrupowaniami w Kartaginie. W efekcie dawny wódz punicki

${ }^{2}$ Matusiak 2015, s. 61-90.

${ }^{3}$ Retrospektywne i nieco prowokacyjne spojrzenie współczesnej historiografii na te kwestie zob. Loreto 2007, s. 246-250; Loreto 2011, s. 192-193.

${ }^{4}$ Hoffmann 1961, s. 73-82; Hoyos 2003, s. 134-135; Hoyos 2008, s. 62-67.

${ }^{5}$ Chroust 1974, s. 275-334; Brizzi 2003, s. 63-78; Eckstein 2005, s. 228-242. 
zmuszony był udać się na wygnanie ${ }^{6}$. Szukając okazji do odwetowej wojny przeciwko Rzymowi, tułał się po dworach hellenistycznych władców ${ }^{7}$. Wygnany przez Antiocha III, znalazł się w końcu na bityńskim dworze Pruzjasza. Rzymianie, od dłuższego czasu pragnący „rozliczyć” Hannibala z jego przewinień, ustalili w końcu miejsce jego pobytu. Dalsza ucieczka nie była możliwa. Zdradzony i opuszczony przez przyjaciół Hannibal popełnił samobójstwo, kończąc tym samym swoją nienawistną wobec Rzymu misję.

Opowieść o Hannibalu, którą rozwijają przede wszystkim Liwiusz, Polibiusz, Appian, Florus, Dio Kassjusz i inni, zawiera szereg wątków pobocznych, posiadając jednak pewien element wspólny, stanowiony przez wyraźną ekspozycję kartagińskiego bohatera. Współczesne badania naukowe wskazują, że literatura antyczna opierała się na konceptualizacjach, które miały na celu dokonanie ekspozycji jednego bohatera głównego ${ }^{8}$. Ten hannibalocentryczny sposób prezentacji nie jest wprawdzie do końca zgodny z prawdą historyczną, gdyż w otoczeniu kartagińskiego wodza działał jeszcze szereg innych dowódców ${ }^{9}$, ale skupia uwagę na jednej postaci i jej całościowo wyświetlonym oraz intrygująco powikłanym losie. Symptomatyczne w tym kontekście wydaje się, że charakterystyczne motywy, które mają sporą reprezentację w literaturze antycznej, znalazły również swoją ilustrację malarską. W odniesieniu do malarstwa selekcjonowanie bogatego dziedzictwa kultury europejskiej i światowej obarczone jest sporym ryzykiem pominięcia któregoś $\mathrm{Z}$ ważnych dzieł. $\mathrm{Z}$ tego powodu, aby uniknąć wrażenia przypadkowości doboru reprezentacji malarskich, konieczne wydaje się wskazanie kluczowych motywów związanych $\mathrm{z}$ działalnością Hannibala, które stały się przedmiotem artystycznego zilustrowania. Wśród nich należy wyróżnić przysięgę złożoną przez Hannibala bogom Kartaginy w okresie jego dzieciństwa, następnie dramatyczną przeprawę przez Alpy, poprzedzoną proroczym snem dowódcy. Do kolejnych motywów zalicza się wyeksponowany motyw słonia, dekapitacja Hazdrubala, dramatyczna bitwa pod Zamą oraz samobójstwo Hannibala ${ }^{10}$.

$\mathrm{Z}$ uwagi na ograniczone możliwości niniejszego opracowania także w obrębie wskazanych powyżej motywów konieczne stało się wyłonienie odpowiednich reprezentacji. Praca nie ma na celu oceny czy jakiegokolwiek wartościowania omawianych dzieł. Kryterium doboru reprezentacji malarskich stanowi przede wszystkim uniwersalność zagadnień, nadających się do modelowego ukazania kulturowej recepcji wzoru cech przypisywanych Hannibalowi. Musimy przy tym pamiętać, że

${ }^{6}$ Wolny 2017, s. 171-188.

7 Günther 1989, s. 241-250.

${ }^{8}$ Christ 1974, s. 361-407; Hampl 1983-1984, s. 9-29.

9 Geus 1994, s. 75-94; Wolny 2016, s. 81-89.

${ }^{10}$ Odrębną kwestię stanowią licznie pojawiające się we współczesnej kulturze motywy nawiązujące do Kartaginy, zob. Siebenmorgen, Hattler i Krause 2005, s. 363-369. 
sztuka nie polega na literalnym odzwierciedleniu historycznych czy legendarnych wątków. Rolę Hannibala mógłby w końcu przejąć ktoś bardziej przyjazny cywilizacji rzymskiej, aniżeli punicki dowódca, który nie był w końcu wzorem cnót, a mimo to cieszył się zainteresowaniem. Tym samym na plan pierwszy wysuwa się pytanie badawcze o źródła atrakcyjności motywu Hannibala pojawiającego się, bądź co bądź, dość reprezentatywnie w wyobrażeniach malarskich. Ustalenie tej kwestii implikuje założenie odpowiedniego instrumentarium postępowania metodycznego, które w pierwszej kolejności musi odwoływać się do analizy antycznych tekstów źródłowych, uwzględniając drogę recepcji treści dotyczących aktywności i symbolicznego wymiaru postaci Hannibala, a następnie do merytorycznej zawartości dzieł malarskich oraz możliwych, przyświecających ich stworzeniu celów perswazyjnych.

Warto zatem rozpatrzeć chronologiczny porządek wydarzeń związanych z Kartagińczykiem i przyjrzeć się malarskim reprezentacjom jego losów od dzieciństwa po śmierć ${ }^{11}$. W takim układzie na plan pierwszy wysuwa się przysięga Hannibala, która w sensie literackim wyświetla motywy działania kartagińskiego dowódcy, a także wyjaśnia religijną legitymizację nienawiści, którą bohater poprzysięga w dzieciństwie. Dane wywodzące się z literatury antycznej będące doniesieniami na temat przysięgi mają różny stopień natężenia ${ }^{12}$, jednakże obok elementu kreującego profil antagonisty Rzymu, spełniają jeszcze szereg funkcji natury politycznej i propagandowej ${ }^{13}$. Z punktu widzenia atrakcyjności motywu literackiego, który mógł być transponowany na wyobrażenia malarskie, szczególne znaczenie posiadają: sprawozdanie Liwiusza ${ }^{14}$, a zwłaszcza Syliusza

${ }^{11}$ Malarskie reprezentacje poszczególnych motywów stanowią prace o zróżnicowanym poziomie artystycznym, co z formalnego punktu widzenia, ściślej - teorii dzieła sztuki, nie zawsze pozwala na tworzenie zestawień i porównań. Jeżeli jednak weźmiemy pod uwagę fakt, że zestawienia zobiektywizowane są w zasadzie wyłącznie do treści dzieła, która stanowi pokłosie literackiej recepcji motywów antycznych, to wówczas spektrum badawcze ulega pewnemu rozszerzeniu. W efekcie pozwala to rzeczywiście wyselekcjonować te sekwencje, których zaistnienie było odpowiedzią na zainteresowanie poszczególnymi motywami związanymi z Hannibalem. Siebenmorgen, Hattler i Krause 2005, s. 366 podkreślają, że historia Kartaginy i jej upadku wielokrotnie stawała się materiałem uznawanym za temat do adaptacji - zarówno literackiego przetwarzania (transparentnym przykładem jest chociażby kontrowersyjna powieść Gustave’a Flauberta „Salambo" - która, mimo że nie traktowała bezpośrednio o Hannibalu, zyskała sporą popularność), jak i szeregu reprezentacji pozaliterackich. Malarstwo, a później również sztuka filmowa, szukały motywów transparentnych, których umiejscowienie było podyktowane różnymi czynnikami, zaś finalny efekt takich reprezentacji, co oczywiste, prezentował zróżnicowany poziom artystyczny.

12 Stosowne podsumowanie i szczegółowe omówienie danych źródłowych na ten temat znajduje się w pracy: Händl-Sagawe 1995, s. 19-23.

${ }_{13}$ Miles 2011, s. 260-279.

${ }^{14}$ Liv. 21.1.4 
Italikusa ${ }^{15}$. Liwiusz opisuje chłopca wiedzionego przez ojca do kartagińskiego ołtarza bogów, przy którym przysięga, że nigdy nie będzie przyjacielem Rzymian. Jego informacja wpleciona zostaje w narrację dzieła, stanowiąc w niej istotny element, umiejscowiony wśród wydarzeń wprowadzających w konflikt rzymsko-kartagiński. Kluczową rolę w literackiej prezentacji tego konfliktu będzie odgrywał Hannibal, a całe doniesienie pochodzące $\mathrm{z}$ „Ab urbe condita” sprowadza się do przekazania zaistnienia przysięgi, jako religijnego aktu ${ }^{16}$. W relacji Liwiusza ograniczono szczegóły, które mogłyby dostarczać atrakcyjnego podglebia dla zaistnienia wyobrażeń malarskich. Nieco inaczej sytuacja ta przedstawia się u Syliusza Italikusa. Konwencja poematu, wzorowanego na dokonaniach Wergiliusza, chociaż stanowczo nie dorównująca inspiratorowi ${ }^{17}$, obfituje w szereg szczegółów, które w istocie czynią scenę przysięgi Hannibala atrakcyjnym motywem literackim, dostarczającym konkretnych informacji, mogących posłużyć za wskazówki do powstania dzieł plastycznych.

Syliusz pisze, że Hamilkar, pomysłowy w pielęgnowaniu gniewu przeciwko Rzymianom, gdy tylko jego syn - Hannibal mógł odróżnić pierwsze słowa, postanowił zasiać wojnę w dziecięcym sercu. Wtedy też powiódł go do świątyni. Miejsce to znajdowało się w środku miasta Kartagina i otoczone było zewsząd cisami i świerkami, zapewniającymi półmrok panujący wewnątrz. W świątyni znajdowały się posągi z żałobnego marmuru - wyobrażenia Belusa, Agenora i Feniksa, wreszcie wyobrażenie siedzącej Dydony, połączonej wiecznym węzłem małżeńskim z Sycheusem. U stóp samobójczyni miał spoczywać miecz frygijski, zaś dalej w głębi świątyni znajdowały się ołtarze innych bogów panujących zarówno na nieboskłonie, jak też zamieszkujących Erebos. W tym miejscu kapłanka w szacie stygijskiej miała przywoływać boskie moce, które reprezentowane były przez Henneę ${ }^{18}$ i Acherona. Wtedy to, jak podaje dalej Syliusz, w świątyni rozgrywają się cuda - ziemia dudni, przerażający świst rozdziera mroki ceremonii (,immugit tellus rumpitque horrenda per umbras sibila"), ognie zapalają się same na ołtarzach („inaccensi flagrant altaribus ignes”), przywołane duchy wzlatują w przestrzeń, a marmurowe oblicze Dydony oblewa się potem („tum magico volitant cantu per inania manes exciti, vultusque in marmore sudat Elissae"). Ojciec, wprowadzając syna do świątyni, uważnie zbadał jego oblicze. Dziecka nie przeraziły jednak tajemne rytuały, próg zbryzgany krwią ani idący od płomieni podmuch, poruszający

15 Sil. 1.70-139.

${ }^{16} \mathrm{Na}$ temat dystrybucji informacji o przysiędze w świecie antycznym zob. Wolny 2005, s. 27-31.

17 Vinchesi 2004, s. 22-26; por. Laudizi 1989, s. 73-75.

${ }_{18}$ Sil. 1.93 poprzez sformułowanie „Hennaeae numina divae”, pozwala wnioskować, że chodzi tu o bóstwo kompetencyjnie zbieżne z rzymską Proserpiną, por. Grimal 1987, s. 304-305. 
skrzypiącymi futrynami wrót świątynnych. W tych okolicznościach Hannibal wypowiada słowa przysięgi - swojej dozgonnej nienawiści wobec Rzymian ${ }^{19}$.

Wyobrażenie tego aktu religijnego musiało być atrakcyjnym motywem w średniowiecznych i renesansowych obrazach, czego istotnym świadectwem jest jedna z części w sześcioczęściowym cyklu historycznym, przedstawionym jako freski w klasztorze św. Jerzego w Stain am Rhaim, zlecone do namalowania Thomasowi Schmidtowi przez opata Davida von Winkelsheima. Praca powstała w latach 1515$16 \mathrm{w}$ nowo wybudowanej sali klasztoru. Thomas Schmidt posiadał współpracowników, prawdopodobnie $\mathrm{z}$ rodziny Holbein ${ }^{20}$, co przypuszczalnie miało niemałe znaczenie dla poszukiwań wzorca w literaturze antycznej. Przysięga Hannibala znajduje się wśród fresków, które zostały zestawione parami i przedstawiają poza tym: Dydonę i Eneasza podczas wznoszenia Kartaginy, wznoszenie Rzymu, przysięgę Scypiona, zdobycie Saguntu przez Hannibala i zniszczenie Kartaginy.

W malarskiej prezentacji Johanna Heinricha Schoenfelda (1609-1682 $)^{21}$ wspomniany akt religijny zachowuje rysy epoki autora, co przede wszystkim uwidacznia się w elementach wystroju sali kolumnowej. Przysięga odbywa się u stóp bóstwa umieszczonego centralnie. Charakterystyczna jest tutaj obecność kobiet i dzieci. Jak się wydaje, poza nadaniem dramaturgii, umieszczenie tych postaci ma swoje znaczenie symboliczne. Autor pracy malarskiej najwyraźniej odchodzi od koncepcji aktu będącego koniuracją wybranych wtajemniczonych, na rzecz pokazania ceremonii egalitarnej, w której jako świadkowie występują przedstawiciele różnych stanów. Podniosłość uroczystości nasuwa skojarzenia oficjalne i nawiązuje do ceremonii państwowej - całkowicie jawnej i stanowiącej w perspektywie czasowej precedens do wyjaśniania poczynań o charakterze politycznym.

Zgoła inaczej akt przysięgi przedstawił Claudio Francesco Beaumont w obrazie „Hannibal jurant haine aux Romain” z 1730 roku. Tutaj ewidentnie dominuje dramaturgia mrocznego rytuału, autor przy pomocy dostępnych sobie środków wyrazu bliski jest oddania specyficznej atmosfery przybycia boskich mocy. Obraz Beaumonta z całą pewnością nie jest statyczny. Dynamika akcji tak szczegółowo oddanej przez Syliusza ma istotny cel uzasadniający obecność bogów powołanych na świadków i w wyraźny sposób ma przekonać, że czyny Hannibala mają najpoważniejszą z możliwych, bo religijną motywację. Przelęknione twarze zgromadzonych pozwalają przypuszczać, że widzą oni cuda, o których pisała literatura antyczna. Elementy dekoratorskie, sposób przedstawienia postaci i cała scena są wizją artystyczną nieodwzorowującą dokładnie opisu Syliusza. Jednakże wyraźnie jest tutaj nawiązanie do atmosfery rzymskiego poematu. Uwidacznia się to $\mathrm{w}$

\footnotetext{
19 Sil. 1.70 i n.

${ }^{20}$ Siebenmorgen, Hattler i Krause 2005, s. 362.

${ }^{21}$ Michaud 2005.
} 
osiągniętej atmosferze grozy i dynamice obrazu. W odróżnieniu od wizji Schoenfelda u Beaumonta nie ma wyobrażenia bóstwa. Przysięgę chłopca odbiera brodaty starzec w białej szacie, udekorowany wieńcem laurowym. Obraz Beuamonta prezentuje również matkę karmiącą - symbol narodu posiadającego wyraźne ideologiczne initium, co nasuwa pewnego rodzaju paralelę z narodem rzymskim. Autor nie rezygnuje również z motywu dzieci, które obecne są podczas przysięgi Hannibala. Obecność postaci dziecięcych, wespół ze wspomnianą sceną karmienia dziecka przez matkę, wydają się czytelnym symbolem informującym, że także i w tym przypadku przysięga związywała całe państwo kartagińskie ${ }^{22}$.

$\mathrm{Na}$ tych prezentacjach nie kończą się nawiązania do słynnej przysięgi Hannibala, co wydaje się potwierdzać żywotność tego motywu. Był on chętnie inkorporowany także przez malarstwo osiemnastowieczne, co potwierdza uwidocznienie przysięgi w dwóch obrazach wystawionych w Royal Academy. Chodzi tutaj o prace Benajmina Westa „Hannibal Taking the Oath” z roku $1771^{23}$ i Thomasa Burges'a „Hannibal ... Swearing Eternal Enemity to the Romans” z 1778 roku $^{24}$. Obraz Westa wyobraża scenę złożenia ofiary ze zwierzęcia, która $\mathrm{z}$ jednej strony nadaje dramaturgii całemu wyobrażeniu, z drugiej zaś nawiązuje do zapewne widowiskowego rytuału taurobolium, polegającej na obmyciu adepta krwią zabijanego zwierzęcia. Tego rodzaju przedstawienie służy zapewne uzasadnieniu powagi aktu, który poprzez ofiarę zobowiązuje adepta - Hannibala do przestrzegania w przyszłości ślubowanych zasad. Podobnie jak w przypadku obrazów Schoenfelda i Beaumonta przez płótno Westa przemawia perspektywa rzymska - czytelne nawiązanie do najlepiej znanej, ale też z perspektywy Europejczyka najbardziej uniwersalnej cywilizacji ${ }^{25}$.

Realizacja przysięgi Hannibala znajduje mocne oparcie w początkach drugiej wojny punickiej (218-201 p.n.e.), kiedy to wódz przeprawia się do Italii najtrudniejszą z możliwych tras - przez Alpy. Drogę pełną niebezpieczeństw czyhających w górskich przełęczach odmalowały antyczne teksty literackie ${ }^{26}$. Wyprawę do Italii

${ }^{22}$ Nieco skromniejsze, pozbawione charakterystycznego rozmachu, wyobrażenie sceny przysięgi przedstawia praca Januariusa Zicka (z końca XVIII wieku), zob. Günther 2010, s. 26.

${ }^{23}$ Royal Academy no. 209.

${ }^{24}$ Royal Academy no. 30.

${ }^{25}$ Podobnie jak w przypadku większości przedstawionych w niniejszej pracy motywów trudno wyczerpać wszystkie reprezentacje, warto jednak zauważyć, że przysięga Hannibala doczekała się również bardziej trywialnych wyobrażeń - o zabarwieniu humorystycznym, czego przykładem może być osiemnastowieczna rycina „The Bedfordshire Hannibal taking the Oath of eternal Enemity” zob. MacDonald 2015, ryc. 4.

${ }^{26}$ Najbardziej dramaturgiczna podstawa relacjonowanych wydarzeń znajduje się u Liwiusza (21.30.1-38.9) i Syliusza Italikusa (3.466-646) a także innych: Plb. 3.44.5-56.5; App. Hann. 4.15-17. Zestawienie dalszych źródeł i dyskusja zob. Händl-Sagawe 1995, s. 193-199. 
poprzedził słynny sen Hannibala, wpisujący się w standardowy konwenans antycznych prezentacji literackich.

Dzieło Jana Miela (1599-1664) $)^{27}$, zatytułowane „Il Sonno di Annibale fra gl'Iberi", stanowiące element dekoracyjny malarstwa sufitowego w Sala del Consiglio Turyńskiego Palazzo Reale ${ }^{28}$, przedstawia Hannibala leżącego na płaszczu wojskowym, podczas gdy uskrzydlony młodzieniec, chwytając jedną dłonią kraj okrycia, drugą wskazuje budzącemu się Punijczykowi zacumowane na morskim brzegu galery. Kiedy dowódca budzi się, wokół niego spoczywają inni żołnierze, pogrążeni wciąż w głębokim śnie. Ponad uskrzydloną postacią posłańca zamieszczone zostało motto: „Genius quo ducit eundum”, mające zakomunikować działanie woli boskiej. Zdobienie części szat młodzieńca motywem gwiazdy na obrazie oraz zastosowanie błękitnej kolorystyki przypuszczalnie miało wzmóc wrażenie estetyczne i symboliczne ${ }^{29}$. Fresk J. Miela, przedstawiciela grupy Bambocciantich, a zatem reprezentanta typowo dekoratorskiego malarstwa, nie odzwierciedla własnej koncepcji artysty. Malarska interpretacja snu Hannibala to element kompleksowego przekazu, wynikającego z przemyślanej teorii dekoratorskiej, wyłożonej przez E. Tesauro ${ }^{30}$. Teoria ta zakładała, że znaczenie udanego dzieła (impresa) stanowi wyzwanie dla wykształconego odbiorcy ${ }^{31}$. Autor miał tu na myśli pewnego rodzaju erudycję odbiorcy, wynikającą z oczytania w literaturze antycznej $j^{32}$.

Wizja senna w literaturze antycznej pojawia się na ogół jako zapowiedź przełomowych wydarzen ${ }^{33}$. Decyzja Kartaginy o ataku na Italię, w iberyjskim aspekcie jej realizacji, była przysłowiowym Rubikonem Hannibala. Proroczy sen, który miał wówczas wyśnić punicki dowódca, posiada szeroką reprezentację w źródłach antycznych. Według Silenosa, którego wersja została skrupulatnie zreferowana przez Cycerona $^{34}$, a także z informacji Liwiusza ${ }^{35}$, Waleriusza Maksymusa ${ }^{36}, \mathrm{Sy}_{-}$ liusza Italikusa ${ }^{37}$ i Zonarasa ${ }^{38}$, wynika, że we śnie Hannibala $z$ wysokości niebios zstępuje boski przewodnik. Punijczyk zostaje zaproszony na zgromadzenie bogów

27 Kren 1978.

28 Rovere 1858.

${ }^{29}$ Wg Ripa 1603, s. 43 (s.v. Benignità) jest to typowa symbolika niebiańska. Błękit symbolizuje bowiem niebo, które jest łaskawe, por. Lammertse 1989, s. 255.

30 Tesauro 1682, s. 400-402.

31 Lammertse 1989, s. 254.

32 Wolny 2020.

33 Hopfner 1937, kol. 2233; Näf 2000, s. 5; Holowchak 2002.

34 Cic. De Div. 1.49 (Silenos = FGH 175 Fr. 2).

35 Liv. 21.22.5-9.

36 Val. Max. 1.7 ext.7.

37 Sil. 3.163-221.

38 Zon. 8.22.9. 
(concilium deorum), gdzie otrzymuje rozkazy. Wedle danych rozkazów ma on iść za swoim tutorem, jednak nie może się odwracać za siebie. Hannibal łamie zakaz i jednak odwraca się. Wtedy dostrzega za sobą obraz zniszczenia wśród hałasu. Widzi bestię, łamiącą drzewa i niszczącą domostwa. Zapytując przewodnika o znaczenie tej wróżby, dowiaduje się, że jest to zniszczenie Italiii3 ${ }^{39}$.

W literaturze antycznej sny jako element narracyjny występują dosyć często ${ }^{40}$. Pełnią określoną funkcję narracyjną i, podobnie jak mowy, do pewnego stopnia zwalniają piszącego $\mathrm{z}$ odautorskiego komentarza ${ }^{41}$, przekazując taką możliwość opisywanemu, bądź celowo wprowadzonemu bohaterowi, który wypowiada się tudzież zostaje obdarowany wizją senną. Element niedopowiedzenia zawarty w przekazach antycznych na temat snów ma zatem swoje konceptualne uzasadnienie. Bezsprzecznie, decydując się na malarskie wyobrażenie tak metaforycznej sceny, również stawiano sobie cele dostosowane do standardu epoki i perswazyjnych pryncypiów oprawy dekoratorskiej. Niewątpliwie ważną rolę w dystrybuowaniu wątku snu Hannibala musiał odegrać poemat Syliusza Italikusa, co uzasadnia zainteresowanie jego twórczością w czasach renesansu i baroku, będące elementem podnoszonej wówczas atrakcyjności poematu antycznego w ogóle ${ }^{42}$. Ta forma literacka stawała się źródłem artystycznie cennych niedopowiedzeń, stwarzających pole do własnej, twórczej interpretacji.

Obraz J. Miela poprzez wyeksponowanie statków nadaje intelektualny trop, który pozwala wykształconemu odbiorcy skojarzyć dzieło malarskie z wizją Syliusza, w której Hannibal ma widzenie senne, podczas którego przystojny młodzieniec pokazuje mu przerażającego smoka. Bestia w okamgnieniu obraca malowniczą krainę w ruiny. Młodzieniec, zapytany przez Hannibala o znaczenie wróżby, wyjaśnia, że przepowiada ona zniszczenie Italii. Tekst Syliusza jest o tyle istotny w związku z pracą Miela, że nie występuje tam wezwanie Hannibala na zgromadzenie bogów. Kartagińczyk we śnie otrzymuje łaskę, która polega na oznajmieniu rozwoju przyszłych wydarzeń. Słowa motta „Genius quo ducit eundum”, przydane dziełu, pochodzą od godła uwidocznionego w dziele „Emblemata” A. Alciatiego ${ }^{43}$. Autor pierwotnej ryciny przedstawił na swoim emblemacie Merkurego na rozdrożu. Symptomatyczne jest, że Merkury odrzuca drogę życia ${ }^{44}$. Na obrazie Miela znajduje się uskrzydlony młodzieniec, wska-

\footnotetext{
39 Wolny 2007, s. 254-264.

40 Zob. Weber 2000; Wolny 2007, s. 253; Schubert 2011, s. 1-20; Vitek 2017, s. 127-152.

41 Peter 1911, s. 255; Wooten 1974, s. 235-251; Pearson 1975, s. 214-230.

42 Muecke 2010, s. 401-424.

43 Cytat nie jest dosłowny, posłużono się bowiem pewnego rodzaju korekturą, zob. Alciati 1548, s. 11, pl. «QUA DII VOCANT EUNDUM».

44 Bowen 1985, s. 222-229.
} 
zujący Hannibalowi kierunek, w którym ten ma podążać ${ }^{45}$. Wątek dotyczący Hannibala został nieomal literalnie przejęty z poematu Syliusza. Pewne odstępstwo od twórczej cytacji malarskiej stanowi to, że w poemacie łacińskim posłańcem jest Hermes (Merkury), natomiast w „Il Cannochiale Aristotelico” jest to przystojny młodzieniec, pięknie wyobrażony przez Miela w anielskiej stylizacji. E. Tesauro dokonał zatem połączenia koncepcji Syliusza Italikusa z „Emblemata” A. Alciatiego, zamieniając Merkurego na uskrzydlonego młodzieńca. Zamiany tej dokonano zapewne dla uniknięcia pogańskich konotacji. Dzięki temu zabiegowi wymowa dzieła, bazująca na syntezie godła, przedstawiającego opowieść zaczerpniętą ze źródła historycznego i obrazu Jana Miela, stała się czytelna - oto działanie woli bożej, obojętnie w jaki sposób poznanej, determinuje losy ludzkości ${ }^{46}$. Podkreśleniu tego celu służy motto dzieła: „Genius quo ducit eundum".

Działanie woli boskiej zesłanej na Hannibala poprzez niebiańskiego emisariusza znajduje również odzwierciedlenie w intersującym obrazie, pochodzącym z wczesnego okresu twórczości Francisca Goi ${ }^{47}$. Wykonane w oleju dzieło, noszące hiszpańskojęzyczny tytuł „Aníbal vencedor contempla por primera vez Italia desede los Alpes" ${ }^{38}$, wyobraża Hannibala, który znajdując się na czołowym planie, z wysokości Alp spogląda na Italię. Twarz dowódcy wyraża podziw i zdumienie, zaś jego dłoń, która zapewne przed momentem przetarła pełne zdumienia oczy, ujmuje kraj hełmu. Geniusz, kładący swoją dłoń na ramieniu Kartagińczyka i znajdujący się za jego plecami, sprawia wrażenie istoty eterycznej, która za moment zniknie, lub wręcz nie jest widoczna dla innych uczestników wyprawy. Po prawej stronie przedstawione zostały wojska Hannibala, powoli schodzące w dolinę, podczas gdy wódz lekko opiera się o konia dosiadanego przez postać, która wydaje się mówić. U stóp Hannibala poleguje rogaty satyr leniwie wylewający wodę z bukłaka, zaś ponad schodzącym w dół wojskiem, na niebie, widnieje bogini Wiktoria, opierająca lewą dłoń na kole, a prawą wznosząca laurowy wieniec. Po lewej stronie można natomiast dostrzec bitewną wrzawę, dość

45 Lammertse 1989, s. 255 zauważa, że w epigramie zamieszczonym przez Alciatiego w ostatniej linijce pluralis „Dii” został zamieniony na „Deus”. Sytuacja ta redefiniuje wymowę całego emblematu, gdyż nie pogańscy bogowie, lecz chrześcijański Bóg determinuje ludzkie losy. Na godle Merkurego widnieje posłaniec bogów/Boga - spełniający ich/jego wolę.

46 Por. Lammertse 1989, s. 255.

47 Hughes 2006.

48 Dzieło przez długi czas (do roku 1993) uważane było za zaginione. Obecnie należy do zbiorów Fundacji Selgas-Fagalde. Inną kwestią jest zwykle obecna w przypadku „cudownie odnalezionych” dzieł dyskusja nad autentycznością obrazu. Podejrzenia tego rodzaju nie oszczędziły również pracy „Aníbal vencedor contempla por primera vez Italia desede los Alpes”, por. Aleksandrowicz 2012, s. 140. 
mocno stonowaną i sprawiającą nieodparte wrażenie, że Goya nie miał pomysłu na tę część swojego dzieła ${ }^{49}$.

Kompozycja obrazu „Aníbal vencedor contempla por primera vez Italia desede los Alpes" wydaje się przeładowana symboliką, co możliwe jest do wytłumaczenia zarówno tym, że mamy do czynienia z młodym artystą, który nie mógł zadowolić się minimalistyczną prezentacją, niezgodną notabene $\mathrm{z}$ duchem jego epoki, jak również faktem, że obraz ten był pracą konkursową, która, jak przytacza H. Mayor, musiała spełniać określone kryteria ${ }^{50}$. Konkurs ogłoszony przez Akademię Sztuk Pięknych w Parmie w roku 1770 był kolejnym konkursem, do którego przystępował Goya, po nieudanych próbach zaistnienia w Akademii Sztuk Pięknych św. Ferdynanda w Madrycie. Przypuszczalnie było to powodem większej determinacji artysty i szeregu przygotowań, które nastąpiły w związku z narzuconym przez Akademię tematem pracy konkursowej. Sama kategoria - malarstwa historycznego - była niebywałym wyzwaniem, chociaż zapewne nie była wówczas zaskakująca. Doprecyzowanie zadania do wyobrażenia sceny przedstawiającej zwycięskiego Hannibala spoglądającego na Italię z alpejskich wysokości („Annibale vincitore, che vimirò la prima volta dalle Alpi L'Italia") ${ }^{51}$ stawiało przed adeptami konkursu zadanie merytorycznego opanowania tematu, w celu stworzenia artystycznej wizji historycznego wydarzenia. Lata 1770-1771 spędził Goya w Italii, tutaj też podjął trwającą około roku pracę nad obrazem, na którą składała się seria szkiców węglem oraz dwóch draftów olejnych ${ }^{52}$. Badania nad formalną stroną pracy artysty zdominowane zostały poprzez próby wykazania jak największej liczby podobieństw, które wylicza w swojej pracy S. Alcolea Blanch. Zalicza się do nich między innymi płaskorzeźba José Ariasa $\mathrm{z}$ Toledo ${ }^{53}$, odpowiadająca za wzorzec konceptualizacji postaci Hannibala, czy wizerunek maszkarona widniejącego na wazie ogrodowej w rzymskiej Villa Borghese $\mathrm{e}^{54}$. W rozważaniach tych w minimalnym stopniu podjęto kwestie konkursowej sceny w literaturze antycznej. Zapewne intencją organizatorów konkursu było zadanie zmierzające do oddania malarskiej wizji stanu bohatera, który podjąwszy już wielki trud, musiał zdać sobie sprawę z ogromu przedsięwzięcia dopiero stojącego przed nim. Jak podkreśla R. Miles, element zaskoczenia, na jaki decydowali się prowadzeni przez Hannibala Kartagińczycy, miał swoją cenę. Uczestnicy wyprawy ponieśli ogromne straty podczas przeprawy alpejskiej. Wyprawa jawiła się zatem jako czyn ponadprzeciętny i epicki

\footnotetext{
49 Alcolea Blanch 1999.

50 Mayor 1955, s. 296.

51 Mayor 1955, s. 296.

52 Sánchez Cantón 1931, s. 182-184; Urrea 1993, s. 59-63.

53 Alcolea Blanch 1999, s. 2.

54 Alcolea Blanch 1999, s. 8-9.
} 
w każdym sensie ${ }^{55}$. Wniosek taki jest oczywiście efektem lektury Liwiusza i jego egzagerowanego opisu, poprzez który chce on jednoznacznie dać do zrozumienia czytelnikowi, że ma do czynienia z trudnym i niezłomnym przeciwnikiem ${ }^{56}$.

Pomimo dość oczywistej intencji konkursowego motywu przewodniego wyrażonego przez określenie „Annibale vincitore” obraz przypisywany Goi pełen jest sprzeczności i mało oczywistych odniesień, dość mocno kontrastujących $\mathrm{z}$ wymową antycznej literatury kształtującej modus operandi opowiadania o przedsięwzięciu Hannibala. Widać to w kilku elementach symbolicznych. Satyr, czy też postać mężczyzny z głową byka, mógłby stanowić personifikację rzeki Pad. Takie ujęcie pozostawałoby w zgodności z założeniami wyłożonymi przez C. Ripa ${ }^{57}$. Wykonywana przez tę postać czynność wylewania wody czyniłaby aluzję do wypełniania rzeki. Hannibal znajdowałby się zatem u jej źródeł, będąc zaledwie na początku swojej drogi. $\mathrm{Z}$ tego powodu określenie Annibale vincitore nie byłoby satysfakcjonujące, ponieważ Hannibal przedstawiony został w momencie, kiedy zaczynał swoje dzieło.

Dostrzegalna wydaje się również korelacja owego inicjalnego momentu w działalności Hannibala z wyobrażoną na niebie sylwetką bogini Wiktorii w orszaku aniołów. Bogini lewą ręką porusza koło rydwanu, na którym siedzi, co może być z kolei nawiązaniem do symboliki fortuny i zmiennych kolei losu. Ujęcie to bezsprzecznie wkomponowuje się w antyczny sposób wyrażania nieodgadnionych kolei losu, w których rolę aktywnego czynnika wydarzeń odgrywa fortuna będą-

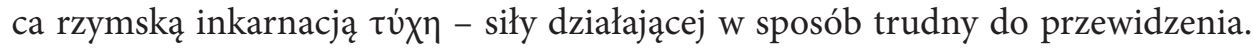
Historia Hannibala, szczególnie w ujęciu Liwiusza, eksponuje zagadnienie sukcesów Kartagińczyka, wskazując jednocześnie na rolę osobistego szczęścia dowódcy („suapte fortuna quadam”) ${ }^{58}$. Kwestia ta pozostawia jednak szerszy margines na negatywne konotacje wydarzeń, bowiem jak wykazał B. Mineo, u Liwiusza znajdują się miejsca, w których działanie fortuna pokrywa się z fatum ${ }^{59}$. Zgodnie $\mathrm{z}$ tą interpretacją Hannibal zamiast być zwycięzcą (Annibale vincitore), może okazać się przegranym (Annibale vinto). Tym bardziej, że dzieło przypisywane Goi prezentuje dość niezrozumiały gest bogini, która prawą ręką wyciąga przed siebie wieniec laurowy, tak jakby chciała wskazywać nim drogę do zwycięstwa. Kierunek ten nie jest tożsamy z miejscem na które spogląda Hannibal. Z połączenia tych alegorycznych gestów można wysnuć dość ogólny wniosek, odnoszący się do niepewności ludzkiego losu.

\footnotetext{
${ }_{55}$ Miles 2010, s. 265-266.

${ }^{56}$ Levene 2012, s. 136-163.

${ }^{57}$ Ripa 1603, passim.

58 Liv. 29.26.5.

${ }^{59}$ Mineo 1994, s. 385-391.
} 
Ciekawym i jak się wydaje kluczowym motywem obrazu jest centralna scena, w której nad postacią Hannibala nachyla się z wysokości wierzchowca inna postać. Wydaje się, że w tym przypadku możliwe są dwie interpretacje. Po pierwsze można założyć, że postacią tą jest Aleksander Wielki. Tłumaczyłoby to umieszczenie podszeptującej Hannibalowi postaci na niesajskim rumaku, jak również to, że postać samego Hannibala stylizowana była na cesarza Trajana zainspirowanego przecież Aleksandrem ${ }^{60}$, czy wreszcie fakt, że sam dowódca kartagiński miał wzorować się na Macedończyku ${ }^{61}$, albo też tak był postrzegany ${ }^{62}$. Malarska wizja tej sceny mogłaby być wyobrażeniem obydwu dowódców przebywających w zaświatach, pewnego rodzaju twórczą reasumpcją pracy Lukiana $z$ Samostat ${ }^{63}$. Z jakiegoś jednak powodu postać rzekomego Aleksandra wyobraża mężczyzna z brodą, podczas gdy wszystkie wizerunki przedstawiają Aleksandra jako bezbrodego młodzieńca - stylizowanego na Achillesa, o zniewieściałym i gładkim obliczu ${ }^{64}$, mogącym przywoływać kontrowersyjne skojarzenie $\mathrm{z}$ pasywnym kochankiem homoseksualnym ${ }^{65}$. Ten z pozoru nieznaczący szczegół wydaje się utrudniać identyfikację postaci podszeptującej Hannibalowi. Poza tym koń, na którym siedzi zagadkowa postać, jest siwkiem, tymczasem nieodłącznym wierzchowcem Aleksandra był Bucefał - koń o czarnym umaszczeniu. Być może z jakiegoś powodu zdecydowano się na antytetyczne przedstawienie Aleksandra nie jako bezbrodego młodzieńca na czarnym koniu, a brodatego mężczyznę na koniu o szarym umaszczeniu. Symbolika takiej inwersji byłaby trudna w interpretacji, jednak jak udało się powyżej wskazać, obraz prezentuje pewnego rodzaju odwrócenia. Persona siedząca na koniu zatem może, ale wcale nie musi, być Aleksandrem.

Pozostaje zatem druga możliwość, która nakazuje identyfikować problematyczną postać z jakimś wpływowym dowódcą w wojsku kartagińskim. Jeżeli weźmiemy pod uwagę początkowy okres drugiej wojny punickiej, pozostaje w zasadzie brat Hannibala - Magon, odpowiedzialny za sprawy związane z dyplomacją Karthalon, tudzież dowódca wojskowy Maharbal. Trzeba przyznać, że wedle świadectwa literatury antycznej tylko ten ostatni miał podpowiadać Hannibalowi, buńczucznie pouczając go o konieczności ataku na miasto Rzym ${ }^{66}$. Chociaż epizod ten budzi spore wątpliwości ${ }^{67}$, to jednak został utrwalony w literaturze antycznej

\footnotetext{
60 Kühnen 2008, s. 165-172.

${ }^{61}$ Liv. 34.14.9; App. Syr. 10.38; Plut. Flam. 21.1-4; Lévêque 1957, s. 654.

62 Breckenridge 1983, s. 111-128.

63 Luc. De dial mort. 12.4.1-7.

64 Polyaen. 4.3.2.

65 Dover 1978, s. 144; por. Schnapp 1997; Ludwig 2002.

66 Liv. 22.51.1-4; Flor. 1.22.19; Amm. Marc. 18.5.6; Zon. 9.1.

67 Halkin 1934, s. 454-457; Hoyos, 2000, s. 610-614. Ponadto na temat Maharbala zob. Brizzi
} 1996, s. 73-80. 
i bezsprzecznie stawał się intersującym motywem, również dla artystycznych wyobrażeń. Założenie to wydaje się znajdować oparcie w samym malarskim przedstawieniu postaci Hannibala, przypominającego raczej egzaltowanego filozofa zdziwionego skalą zjawiska, którego się podjął. Postawiony w centrum obrazu Hannibal, z jednej strony popychany przez uskrzydlonego emisariusza niebiańskiego, z drugiej zaś wystawiony na podszepty swojego dowódcy, może sprawiać wrażenie postaci zagubionej i przerażonej ciężarem podjętego przedsięwzięcia. Z całą pewnością Hannibal Goi nie jest tu przedstawiony jako decyzyjny dowódca, który z błyskiem w oku i opisaną przez literaturę charyzmą odważnie podejmuje wielkie wyzwanie. Wszystkie atrybuty nieustraszonego i działającego dowódcy przejmuje postać na koniu. Ta symboliczna scena jest być może aluzją odnoszącą się do politycznych stosunków w Europie XVIII wieku, gdzie dynastyczne miraże i oktrojowane protekcje ustawiały na piedestałach postaci niekoniecznie utalentowane. Goya, choć malarz bezsprzecznie wybitny, doświadczył tego osobiście, kiedy korzystał z protekcji José Nicolasa de Azara lub kiedy przedstawiał się z imienia jako „Francesco” z włoska, zamiast Francisco - prawidłowo z hiszpańska. Paradoks polegał na tym, że w jego przypadku zastosowane protekcje nie przyniosły spodziewanego sukcesu.

Dramatyczny przebieg górskiej wyprawy znalazł odzwierciedlenie w obrazie Heinricha Leutemanna (1824-1905), gdzie pośród trudów ekspedycji w centralnym miejscu przedstawiony został wódz Hannibal, który nie bacząc na niebezpieczeństwa, wydaje rozkazy. Obok kartagińskiego dowódcy na zranionym strzałami słoniu podąża postać w kapturze, która odwrócona jest tyłem, aby nie było można stwierdzić, kim jest ${ }^{68}$. Część żołnierzy wychodzi z przełęczy. W tym miejscu przedstawione są martwe zwierzęta i zniechęceni ludzie. Atmosferę ogólnego nieładu wzmagają sceny, gdzie silniejsi uczestnicy wyprawy udzielają pomocy upadającym. Na koniu pośród wrzawy podąża jakiś wyższy oficer kartagiński, do pleców którego łapczywie przylgnęła młoda niewiasta. Pukiel jasnych włosów i jasna karnacja skóry mogą zdradzać, że jest to Galijka, która zapewne niedawno zawarła bliższą znajomość z Punijczykiem. Scena ta wskazuje wyraźnie, że poddowódca Hannibala nawet $\mathrm{w}$ tak trudnej chwili nie potrafi zrezygnować z miłostek. Jego odwrócona od zgiełku głowa i małe lisie oczka wydają się sugerować, że wypatruje on jakiegoś górskiego uskoku, łatwiejszej drogi dla zabezpieczenia siebie i swojej niedawnej zdobyczy. Wszystko to dzieje się za plecami Hannibala, podczas gdy prawdziwie apokaliptyczne sceny rozgrywają się dopiero przed nim. Na stromym górskim podejściu ludzie przewracają się bądź z trudem zyskują równowagę. Ci, którzy wdrapali się na najwyższe przedstawio-

${ }^{68}$ To niedopowiedzenie otwiera drogę interpretacji biegnącej w stronę dostrzeżenia w zakapturzonej postaci Geniusza. Na temat przedstawień geniuszy zob. Rink 1933. 
ne przez Leutemanna miejsce, też nie są całkiem bezpieczni - to właśnie tam ogromny słoń ześlizguje się ze skalistej grani i upada w przepaść. Wraz z nim spadają również ludzie. Można by rzecz, że obraz ten nie wyraża żadnej nadziei, zniechęcenie podsyca absurdalność wyczynu Hannibala, który jako jedyny wydaje się wierzyć w powodzenie tej ekspedycji. Heinrich Leutemann dodał jednak w swojej pracy jeden charakterystyczny symbol, poprzez który komunikuje sens przedstawionego niezłomnego wysiłku - symbolem tym jest ptak, który przelatuje ponad górskimi szczytami. Być może jest to orzeł - symbol rzymskiej aquili, przywołany tu dla nadania czytelnego uzasadnienia podjętych poświęceń. Zgodnie z greckim standardem, którego w przypadku tej prezentacji również nie możemy wykluczyć, orzeł był symbolem powodzenia. Wedle „Iliady” w istocie stanowił dobry znak ${ }^{69}$. Ptak ten miał konotacje królewskie, stanowił symbol królów pochodzących od Zeusa ${ }^{70}$.

Oczywiście zasadnicza kwestia dotyczy rozstrzygnięcia, dla kogo w istocie znak ten miałby być dobry: czy dla Hannibala, czy dla Rzymian. W krótszej perspektywie czasowej Kartagińczyk osiągnął przecież sukces, jednakże w dłuższej ostatecznymi zwycięzcami okazali się Rzymianie. Tego rodzaju symboliczna dwuznaczność będzie właściwa również dla kolejnych prezentacji powiązanych z przeprawą Hannibala przez Alpy.

Atmosfera, którą poprzez swój obraz „Snow Storm: Hannibal and His Army Crossing The Alps" oddał w roku 1812 Joseph Mallord William Turner, jeszcze zyskała na dramaturgii. Apokaliptyczny wizerunek wyprawy niewątpliwie wzmagał podziw dla Hannibala. Autor eksponuje rozległą italską krainę, która rozciąga się przed podążającymi przez trudy ekspedycji Kartagińczykami. Trudność podstawową stanowi tutaj burza śnieżna, która z powodzeniem prowadzi do skontrastowania romantycznego przedstawienia „ziemi obiecanej”71, w pewnym sensie stawiając przed widzem pytanie o możliwość osiągnięcia celu ekspedycji. Kwestia ta pozostaje otwartym polem dyskusji, jednak pierwotne zamysły autora rozświetlają jego historyczno-literackie zainteresowania. Współczesne badania nad twórczością J.W. Turnera mają szeroką reprezentację $e^{72}$, która odkrywa merytoryczne przygotowanie autora i wyjaśnia, że Turner nie tylko przemyślał koncepcję dzieła, ale także w sposób planowy dokonał wyboru tematyki pracy. W kwestii kolorystyki obraz Turnera nasuwa pewne skojarzenia z krytykowanym dziełem Richarda Willsona „The Destruction of Niobe’s Children”73. Skądinąd nie sposób oprzeć się również wrażeniu pewnego rodzaju chromatycznego podobieństwa względem dzieła

${ }^{69}$ Il. 8.247.

${ }^{70}$ Il. 24.292-311; Ael. N.A. 12.21; Rostropowicz 2002, s. 154.

${ }^{71}$ Clark 1973, s. 234.

72 Finberg 1909; Finberg 1961; Gage 1969; Butlin i Joll 1977; Wilton 1979.

${ }^{73}$ Krytyki tej powstałej w 1768 roku pracy dokonał Joshua Reynolds, zob. Matteson 1980, s. 387. 
„River near a Town, by Moonlight”, które namalował Aert van der Neer. Przede wszystkim jednak nie pozostawał tutaj przypadkowy czas stworzenia obrazu. Nawiązując do europejskiego zainteresowania masywem alpejskim ${ }^{74}$, Turner podjął się przedstawienia tematu, który pozostawał niezwykle w jego czasach aktualny, gdyż nawiązywał do epopei Napoleona, który w maju 1800 roku przekroczył ze swoim wojskiem Wielką Przełęcz Św. Bernarda ${ }^{75}$.

Oczywiście Turner nie był jedynym, który operował tym nawiązaniem. Znacznie bardziej bezpośrednim motywem posłużył się Jacques-Louis David, który swoje wielokrotnie powtarzane dzieło zatytułował wprost „Bonaparte franchissant le Grand-Saint-Bernard"76. Dzieło malarskie Davida wyobraża Napoleona dosiadającego narowistego rumaka, który staje dęba na szczycie alpejskiego masywu. Twarz młodego dowódcy wyraża zdecydowanie, spokój i niebywałą pewność. Ledwo dostrzegalna, ale jednak wyraźna inskrypcja na skałach odsłania nakreślone na niej imiona innych wielkich dowódców: Hannibala i Karola Wielkiego, którzy przekroczyli Alpy przed Napoleonem. Przeprawa przez Alpy z pewnością rozpalała wyobrażenie o sensacyjnym czynie. Wedle tego wyobrażenia Napoleon stawał się „nowym Hannibalem” 77 .

Obydwie prezentacje dotykają $\mathrm{w}$ istocie tego samego zagadnienia, jednak praca Davida jako wcześniejsza (1801-1803), nie miała jeszcze tej negatywnej dla działań Napoleona siły, co praca Turnera. Jak słusznie konkluduje w swojej rozprawie Lynn R. Matteson, Hannibal jako bohater obrazu „Snow Storm: Hannibal and His Army Crossing The Alps" został obciążony niebywałym balastem symbolicznym, stając się idealnym precedensem, tworzącym okazję odniesienia się do spraw aktualnych - Kartagińczyk zyskiwał bowiem ogromną symboliczną moc, przeistaczając się we współczesną hybrydę Hannibala-Napoleona ${ }^{78}$. W kilka lat po premierze obrazu Turnera znany był już wynik bitwy pod Waterloo, która czyniła to dzieło nieomal profetycznym, jeśli oczywiście $\mathrm{w}$ interpretacji weźmiemy pod uwagę to, że Hannibal przekraczający Alpy służył tutaj za oczywistą metaforę czynów Napoleona ${ }^{79}$. Co więcej, spełniły się jako proroctwo słowa z poematu Turnera „Fallacies of Hope”, które w kluczowym passusie brzmią: „Capua’s joys beware!”. Wynika z tego, jak podkreśla Matteson, że nadzieja człowieka zostaje zawiedziona przez bałwochwalczą ambicję i dekadencję. Paralela pomiędzy przegranym Kartagińczykiem a pokonanym Korsykaninem, spowodowała dodatkowo, że dopisek

\footnotetext{
74 Nicolson 1959; Stanzel 1964, s. 122-132.

75 Mathieu 2015, s. 147.

76 Bordes 2007, s. 83.

77 Schoch 1975, s. 56; Siebenmorgen, Hattler i Krause 2005, s. 362.

78 Matteson 1989, s. 296.

79 Bordes 2007, s. 33 i n.
} 
o Hannibalu na obrazie Davida w kontekście pracy Turnera przydał zobrazowaniu Napoleona ironicznego wymiaru ${ }^{80}$.

Wyprawę przez Alpy wyobraził w swoim dziele również Alfred Rethel (18161859), twórca drzeworytu, który ostateczny kształt malarski zyskał w roku 1872 za sprawą Blättera. Pierwotnie Rethel przedstawił przeprawę Kartagińczyków w sześciu odsłonach. Pierwsza scena pokazuje starego człowieka, który będąc już zapewne na miejscu, po wyprawie opowiada o jej trudach. Najpierw pokazana jest przeprawa przez rzekę Durance, dalej zilustrowano walki z plemionami zamieszkującymi Alpy, następnie rozpacz Kartagińczyków wśród lodu i śniegu, aby w następującej na końcu odsłonie przedstawić Hannibala, który wskazującym gestem odkrywa przed swoimi żołnierzami Nizinę Padu ${ }^{81}$.

Nie ulega wątpliwości, że wśród motywów związanych z Hannibalem szczególne znaczenie ma związanie postaci Kartagińczyka z rzadkim i tajemniczym zwierzęciem, którym był słoń. W świecie starożytnym znano głównie dwa rodzaje słoni: indyjskie (Elephas indicus), ogromnych rozmiarów Elephas maximus, oraz afrykańskie (Elephas africanus) znane jako jako Loxodanta africana i Loxodanta africana cyclotis. Dane o słoniach zachowały się z cywilizacji egipskiej. Polityka Tutmozisa I (1493-1482 p.n.e.) oraz jego wnuka Tutmozisa III (1479-1426 p.n.e.), realizowana poprzez tereny Syrii w kierunku Eufratu, dawała sposobność do urządzania polowań na słonie ${ }^{82}$. Grecy posiadali wprawdzie imponującą wiedzę na temat słoni, jednakże jej zasób narastał sukcesywnie. Najpełniejszy opis słonia poczyniony został dopiero przez Arystotelesa, z dzieła którego korzystali w znacznej mierze Pliniusz i Solinus. Rozmaite legendy o słoniach przytaczają Juba, Plutarch i Elian ${ }^{83}$. Wzmianki o militarnym zastosowaniu słonia pochodzą natomiast dopiero z czasów epoki Aleksandra i jego sukcesorów ${ }^{84}$. Rzymianie spotkali się zaś ze słoniami w okresie wojny z Pyrrusem, który jako pierwszy przywiózł te zwierzęta do Italii. Hannibal na większości obrazów przedstawiony jest w towarzystwie słoni. Jest to związek szczególnie silnie oddziałujący na koncepcje wizualizacji tych zwierząt w malarstwie. Wyraźną cechą wspólną są przesadzone rozmiary tych zwierząt.

${ }^{80}$ Matteson 1989, s. 296: „By then the historical analogy between the vanquished Carthaginian and the defeated Corsican had even greater aptness, as Turner duly noted by his insertion in one vignette of the image from David's proud Napoleon (...), an artistic «borrowing» surely made with a sense of irony".

${ }^{81}$ Siebenmorgen, Hattler i Krause 2005, s. 376.

${ }^{82}$ Scullard, s. 27. Daty panowania władców Egiptu podano, opierając się na chronologii Krausa, zob. Schneider 2001, s. 367.

${ }^{83}$ Ernout 1952, s. 108; Morta 2004, s. 106.

${ }^{84}$ Pierwsza źródłowo poświadczona wzmianka o wykorzystaniu słoni w bitwie, związana jest z opisem starcia pod Gaugamelą (331 p.n.e.). Chociaż z uwagi na charakter źródła („Fragmentum Sabbaiticum"), informacja ta bywa kwestionowana. W każdym razie ewentualne wykorzystanie tam słoni nie miało większego znaczenia taktycznego, zob. Devine 1975, s. 374-384. 
Widoczne jest to oczywiście na monumentalnym fresku Jacopo Ripanda, gdzie zaprezentowany został słoń gigantycznych rozmiarów unoszący na swoim grzebiecie Hannibala ${ }^{85}$. Szczególnym przykładem tego rodzaju wyolbrzymienia jest praca Henri'ego Paula Motte (1846-1922), który przedstawił przeprawę Hannibala przez rzekę Rodan. Co ważne, Motte jako malarz historyczny i pejzażysta był również osoba piszącą o sztuce. Obraz przedstawia zgodny z zapamiętaną w źródłach antycznych tradycją wyczyn polegający na wprowadzeniu słoni na mobilne pomosty, dla niepoznaki najpierw stanowiące przedłużenie lądu, później zaś, po wejściu na nie zwierząt, odczepione i holowane jak tratwy. Szczegółem godnym odnotowania jest to, że na grzbietach słoni na obrazie Motte'go znajdują się wieże strzelnicze zaopatrzone w kilkuosobowe załogi, co jeszcze bardziej wzbudza respekt przed tymi zwierzętami ${ }^{86}$. Bez wątpienia prezentacje tego rodzaju mogły w szczególny sposób wpływać na rozbudzenie wyobraźni, nie dziwi przeto fakt, że próbowano przekonać się o praktycznych aspektach wyprawy, odgrywając jej przebieg. Takiego wyczynu dokonał Richard Halliburton, co zostało opisane w „Neue Zürcher Zeitung” w $1935^{87}$, wzbudzając na nowo zainteresowanie przebiegiem wyprawy Hannibala. Osobliwy happening przysporzył oczywiście popularności autorowi, o czym świadczy chociażby wymowne brzmienie pierwszej części tytułu książki „Don’t die in bed”, której autorem jest John H. Alt ${ }^{88}$.

Niewątpliwie wśród wątków i motywów składających się na wyobrażenie dziejów Hannibala istotne znaczenie miał moment, w którym ostatecznie przekreślone zostały jakiekolwiek szanse na odniesienie zwycięstwa nad Rzymianami ${ }^{89}$. Stało się to wówczas, gdy ekspedycja dowodzona przez brata Hannibala - Hazdrubala, poniosła klęskę w bitwie nad Metaurusem (207 p.n.e. $)^{90}$. W literaturze antycznej ten symptomatyczny moment podkreślono poprzez wyeksponowanie motywu dekapitacji naczelnego dowódcy drugiej znanej kartagińskiej wyprawy do Italii ${ }^{91}$. Rzymianie, aby upewnić kartagińskiego wodza o przegranej jego brata, przesłali mu do obozu odciętą głowę Hazdrubala. Relacja ta, wykorzystana w literaturze antycznej przez szereg autorów, między innymi Liwiusza ${ }^{92}$, Frontinusa ${ }^{93}$, Syliusza Ita-

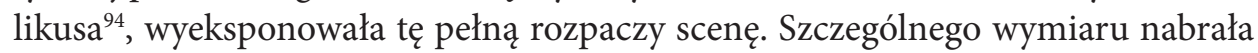

${ }^{85}$ Sommella i Tittoni Monti, 1996, s. 36.

${ }^{86}$ Siebenmorgen, Hattler i Krause 2005, s. 378.

${ }^{87}$ Neue Zürcher Zeitung z dnia 23 lipca 1935 („Wer ist Richard Halliburton? ”). Autor korzysta z francuskiego przekładu fragmentów tego tekstu za: Mathieu 2015, s. 141.

${ }^{88}$ Alt 2013.

${ }^{89}$ Zimmermann 2008, s. 59.

${ }^{90}$ Oehler 1897.

${ }^{91}$ Marks 2008, s. 66-88.

${ }_{92}$ Liv. 27.51.11.

93 Front. 2.9.2.

${ }^{94}$ Sil. 15.813. 
ona w poetyckiej wersji wydarzeń przekazanej przez Syliusza Italikusa. Autor ten opisuje nocny powrót zwycięskich wojsk rzymskich. Zapewne mając na uwadze zachowanie dramaturgii opisu, Syliusz skraca prawdopodobny sześciodniowy czas marszu („die sexto”) wzmiankowany u Liwiusza ${ }^{95}$ i każe rozgrywać się wydarzeniom jeszcze tej samej nocy po bitwie ${ }^{96}$. Podążający na czele pochodu konsul Klaudiusz Neron przynosi zatkniętą na długiej włóczni i skierowaną ku górze głowę zabitego wodza, zaś czyniąc to, wyrzeka Hannibalowi, że oto Rzymianie odpłacili mu za Kanny, za Trebię i za brzegi Trazymenu („Tum Nero procera sublimia cuspide portans / ora ducis caesi «Cannas pensavimus», inquit / Hannibal, et Trebiam et Trasimenni litora tecum/ fraterno capite...") $)^{97}$.

Nie bez znaczenia wydaje się tutaj dalsza część wypowiedzi Syliusza, który ustami konsula Nerona szyderczo napomina dowódcę kartagińskiego, nakazując mu, aby szedł w bój i podwoił swoje walki pełne podstępów („duplica nunc perfidia bella”), ponieważ zapłata już pozostaje („hunc praemia restant”) ${ }^{98}$, także dla tych, którzy chcieliby wejść do Italii i służyć w wojsku kartagińskim. W odpowiedzi Kartagińczyk miał z trudnością powstrzymywać się od płaczu, co ewidentnie wskazuje na świadome skontrastowanie wykreowanego w literaturze okrutnika z ludzkim odruchem żalu. Bezsprzecznie ten aspekt stał się motywem przewodnim obrazu olejnego „Annibale guarda la testa di Asdrubale” autorstwa Giovanniego Battisty Tiepolo ${ }^{99}$. Powstałe w latach 1725-1730 dzieło przedstawia sylwetkę kartagińskiego wodza, który wyszedł z namiotu wojskowego, zaalarmowany zapewne naglącą sytuacją. Na dole, po lewej stronie obrazu znajduje się leżąca na ziemi odcięta głowa młodego mężczyzny. Motyw ten wydawał się na tyle interesujący i wymowny zarazem, że obraz został skopiowany i przeniesiony węglem na papier przez Jean-Honoré Fragonarda.

Dzieło autorstwa Tipolo wyróżnia się jednak jeszcze w jeden istotny sposób. Hannibal wyobrażony przez artystę opuszcza namiot wojskowy w piękny i pogodny dzień. Aura otoczenia zupełnie nie ma ponurego charakteru, którego elementem byłoby tragiczne wydarzenie związane z dekapitacją młodego kartagińskiego dowódcy. Autor pominął zatem atmosferę nocnego zamieszania związanego z przyniesieniem głowy do obozu Hannibala i ciskaniem kalumnii przez konsula Nerona. Niewątpliwie intencją artysty było przede wszystkim to, aby odcięta głowa nie została od razu zauważona ${ }^{100}$. Być może dla symbolicznego podkreślenia

95 Liv. 27.50.1.

96 Sil. 15.811.

97 Sil. 15.813-816.

98 Sil. 15. 817-818.

99 Kunsthistorisches Museum Vienna.

100 Reprodukcja obrazu zamieszczona w pracy Günther 2010, s. 124, nie oddaje w pełni szczegółów pracy malarskiej G.B. Tiepolo. 
realnych zagrożeń, które częstokroć bywają niezauważone bądź zauważane są zbyt późno.

Sportretowana na obrazie Tiepolo twarz Hannibala nie jest wolna od wyrazu uczucia żalu po śmierci brata - $\mathrm{w}$ istocie powyżej omówiony fragment poematu Syliusza Italikusa, musiał stanowić zasadnicze ogniwo inspiracji. Wspomniany już motyw żalu Hannibala wyeksponowany przez Syliusza Italikusa, zdaniem P. Matusiak ${ }^{101}$, pozwala znajdować cechy konstruujące pojęcie Poenus humator występujące u Lukana ${ }^{102}$. W tym przypadku zachowanie Hannibala, który z godnością opłakuje śmierć barta, ale także wyprawia pogrzeb Emiliuszowi Paulusowi i Tyberiuszowi Grakchusowi ${ }^{103}$, a następnie Markowi Klaudiuszowi Marcellusowi ${ }^{104}$, zostaje zestawione $\mathrm{z}$ okrucieństwem Rzymian ${ }^{105}$. Podkreślenie ludzkiej reakcji Hannibala musiało być motywem artystycznie atrakcyjnym, który w jakimś sensie może stanowić samousprawiedliwienie dla dowódców prowadzących wojny.

Bez wątpienia ciekawym elementem obrazu Tiepolo jest motyw odciętej głowy ${ }^{106}$. Jest to nawiązanie do historii św. Jana Chrzciciela, którego odciętą głowę trzyma Salome na talerzu, spełniwszy swój niecny kaprys. Salome chętnie zestawiana była $\mathrm{w}$ sztuce $\mathrm{z}$ wizerunkami innych kobiet, którym zwłaszcza $\mathrm{w}$ epoce fin de siècle przypisywano cechy krwiożercze i demoniczne. W tym zestawieniu znalazła się również heroina głośnej dziewiętnastowiecznej powieści G. Flauberta „Salambo" 107.

Symptomatyczną kulminacją tragicznych losów Hannibala jest porażka jego dowódczych umiejętności, która nastąpiła w bitwie pod Zamą (202 p.n.e.), bo tak w literackiej wersji dziejów Punijczyka należałoby ją interpretować. Sztuki plastyczne w wyszukany sposób uzupełniają to wyobrażenie. Pierwotny szkic do tapiserii znajdujący się w zbiorach graficznych Luwru, który przygotował G.F. Pennini, nie pokazuje wprost klęski Kartagińczyka, przeciwnie, odkrywa przed oglądającym niezłomną szarżę słoni-gigantów, które rozbijają rzymskie wojska. Jedynie wyposażony w odpowiednią wiedzę historyczną odbiorca jest w stanie pojąć przesłanie tego obrazu. Hannibal ponosi klęskę nie na skutek braku umiejętności, lecz z powodu pojawienia się lepiej przygotowanego i dzielniejszego rywala, którym jest Scypion Afrykański.

W koncepcji malarskich wyobrażeń z klęską Hannibala koresponduje praca plastyczna Heinricha Leutemanna, stanowiąca jedno z nielicznych wyobrażeń

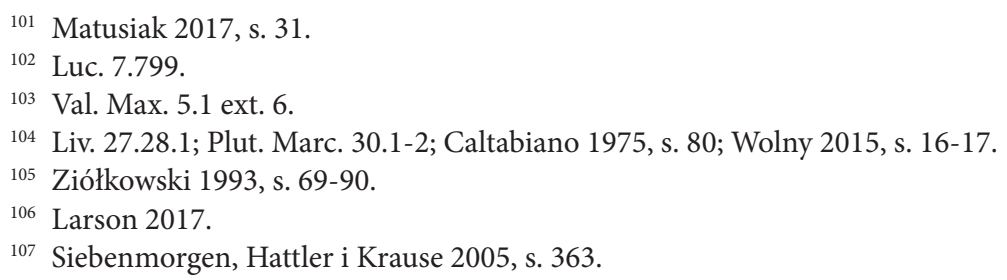


zwycięskich Kartagińczyków pod Kannami (216 p.n.e.). Hannibal z wysokości konia nadzoruje tam akcję zbierania złotych pierścieni ${ }^{108}$, które miały zostać odesłane do Kartaginy, jako dowód ogromnej krwawej ofiary, w której złożono Rzymian ${ }^{109}$. Zama stanowi swoisty odwet za klęskę Rzymian, a w zamyśle Penniniego moralne nawiązanie do zawsze możliwego zaistnienia sprawiedliwości. Z perspektywy znajomości dalszych losów Hannibala niniejszy obraz przemyca jeszcze jedną istotną informację - Kartagińczyk, pomimo klęski, nie poddaje się - jeszcze przez bez mała dwadzieścia lat przy pomocy wszelkich środków nadal działa przeciwko Rzymianom, wbrew przeciwnościom losu i niechęci swoich pobratymców.

Samobójstwo Hannibala stanowi kulminacyjny punkt w literaturze antycznej opisującej dzieje tej postaci. Nie ulega wątpliwości, że motyw ten jest koherentny z całościowymi dziejami Hannibala. Ponadto wkomponowuje się w ewolucję problemu samobójstwa jako prezentacji literackiej. Jak zauważa F. Thalheim, w poematach Homerowych wspomniane są dwa samobójstwa: Epikasty - matki Edypa i Ajasa, przy czym obydwa popełnione są ze wstydu, bez słowa nagany. Myśli o samobójstwie zdradza także Odyseusz. Obawę, że mogłoby dojść do samobójstwa, wyraża również Achilles w Hadesie. Thalheim podkreśla, że bardziej posępny pogląd na życie znajduje się u Hezjoda, a jeszcze bardziej u Teognisa, który niemalże zaleca biedakowi samobójstwo. Homerycki sposób obrazowania znajduje jeszcze odzwierciedlenie w twórczości Aischylosa. Już bowiem u Sofoklesa samobójstwo jest częste, co więcej, traktowane jest poważnie, jako wyzwolenie od hańby albo wielkiego nieszczęścia ${ }^{110}$. W przypadku Ajasa przedstawione jest nawet na scenie ${ }^{111}$. Co ważne, nigdzie nie jest przedstawione jako naganne, zaś przez Eurypidesa jest niemalże gloryfikowane ${ }^{112}$. Samobójstwo Hannibala jest zatem modelowym aktem tragedii greckiej - popełnione zostaje w sposób spektakularny, służąc jednak nie tyle wyzwoleniu od hańby, ale jej zapobieżeniu.

Nie bez znaczenia był tutaj również wiek Hannibala w momencie popełnienia samobójstwa - Hannibal ukończył już sześćdziesiąty rok życia. Można zatem przypuszczać, że był zgorzkniały i zrezygnowany. Sytuacja, w której się znalazł, też nie była szczególnie optymistyczna. Kartagińczyk, po opuszczeniu swojej ojczyzny ze statusem banity, udaje się bowiem na tułaczkę po dworach hellenistycznych. Wśród szeregu przystani, które odwiedza w trakcie swojej podróży, szczególne znaczenie mają dwie: wizyta na dworze władcy państwa Seleukidów Antiocha III

108 Motyw pozyskania pierścieni przez Kartagińczyków przekazany został w literaturze antycznej Liv. 23.12.1.

109 Siebenmorgen, Hattler i Krause 2005, s. 378.

110 Thalheim 1921, kol. 1134.

111 Faber 1967, s. 441-445.

112 Thalheim 1921, kol. 1134. 
i pobyt w Bitynii u jej króla Pruzjasza. Hannibal ze swoją wiedzą i doświadczeniem mógł być użytecznym doradcą znajdującym się w kręgu jednego lub drugiego władcy. Obaj jednak najwyraźniej traktowali tę znajomość wyłącznie merkantylnie, co stało się powodem, dla którego dawny wódz punicki musiał opuścić Antiocha III i przypuszczalnie został zdradzony przez Pruzjasza. Miało to ostatecznie zmotywować Hannibala do odebrania sobie życia. Liwiusz ${ }^{113}$, Plutarch w „Żywocie Tytusa Flamininusa"114, a także Waleriusz Maksymus ${ }^{115}$ i Nepos ${ }^{116}$ dostarczają najbardziej szczegółowych informacji na temat ostatnich chwil życia Hannibala, a także relacjonują różne wersje wydarzeń związanych ze sposobem popełnienia samobójstwa.

Generalnie literatura antyczna wskazywała na zażycie przez Hannibala trucizny, którą zwykł zawsze nosić przy sobie - porcja trucizny ukryta była w ozdobnym pierścieniu noszonym przez Kartagińczyka. Za sprawą Plutarcha do literatury antycznej trafił również przekaz o zadzierzgnięciu płaszcza na szyi Hannibala. Okryciem tym miał poruszać niewolnik oparty o plecy ofiary w celu jej uduszenia. Ponadto, także dzięki autorowi z Cheronei, dowiadujemy się o rzekomym wypiciu przez Hannibala byczej krwi, która tężejąc w przewodzie pokarmowym, wywoływała torsje i powodowała śmierć w okropnych męczarniach. Nietrudno znaleźć uzasadnienie transparencji motywu samobójstwa Hannibala dla późniejszych wyobrażeń artystycznych, zarówno na gruncie literatury pięknej, jak i prezentacji malarskich. Pomijając podjętą w nauce próbę wyjaśnienia rzeczywistej metody samobójstwa, wybranej przez Hannibala ${ }^{117}$, a także obszerne badania nad kulturowym wymiarem samobójstwa w świecie starożytnym ${ }^{118}$, bez wątpienia należy przyznać, że motywem artystycznie atrakcyjnym jest scena zażycia trucizny. Praca plastyczna, będąca miniaturą zamieszczoną do francuskiego przekładu „Des cas des nobles hommes et femmes” (z lat 1409-1410) Giovanniego Boccaccia, przedstawia starego mężczyznę stojącego w otoczeniu klasztornego wnętrza i trzymającego w dłoni truciznę, na tej samej ilustracji mężczyzna ten leży martwy, co stanowiło konwencję graficznej prezentacji wydarzeń następujących kolejno po sobie ${ }^{119}$.

Praca plastyczna H. Leutemanna przedstawiająca scenę śmierci Hannibala ${ }^{120}$ najbardziej odpowiada wizjom przekazanym przez antyczną literaturę. Dawny

\footnotetext{
113 Liv. 39.51.1 i n.

114 Plut. Flam. 20.8-11.

115 Val. Max. 9.2 ext.2.

116 Nep. Hann. 12.3-5.

117 Domitilla Campanile 2000, s. 123-128.

118 Grise 1982.

119 Lancel 2001, il. 29.

${ }^{120}$ Günther 2010, s. 186.
} 
dowódca kartagiński, przedstawiony przez artystę na pierwszym planie, znajduje się w pałacowym pomieszczeniu. Siedząc $\mathrm{z}$ triumfalnie wyciągniętą w górę zaciśniętą pięścią prawej dłoni, trzyma jednocześnie w lewej ręce naczynie z trucizną. Tymczasem stojący u wejścia niewolnik dostrzega nadciągających Rzymian. Niedoszłych opresorów Hannibala widać również w wejściu umieszczonym w tle głównych wydarzeń. Nawiązanie to zgodne jest z opisami zawartymi $\mathrm{w}$ antycznych tekstach literackich. Ciekawym wątkiem prezentacji Leutemanna są punkty zbieżne z dramatem Ch.D. Grabbego „Hannibal”, w którym końcowy piąty akt opisuje scenę wspólnego samobójstwa, które wraz z Kartagińczykiem popełnia jego wierny sługa Turnu. Grabbe określił go wprawdzie jako „ein Negerhäuptling", które to określenie na sztychu Leutemanna bardziej pasuje do osoby znajdującej się przy wejściu do pomieszczenia. Nie zmienia to wszakże faktu, że w prezentacji Lautemanna na kolanie Hannibala spoczywa mężczyzna, który bądź zanosi się od płaczu, bądź kona. Druga możliwość wydaje się bardziej adekwatna, bowiem scenę opłakiwania decyzji wodza o jego odejściu odgrywa mężczyzna stojący na dalszym planie po prawej stronie. Jeżeli scenę samobójstwa Hannibala połączymy z treścią piątego aktu tragedii Grabbego, to ma ona szanse zyskać wymiar eschatologiczny. W dziele scenicznym niemieckiego autora śmierć interpretowana jest jako przejście do innego wymiaru egzystencji. Turnu mówi przecież swojemu panu, że nie będzie ona niczym innym jak tylko zrzuceniem z siebie skóry, tak jak czynią to węże na wiosnę. Tego rodzaju interpretacja stanowi konceptualne wzmocnienie postawy Hannibala i wydaje się przesądzać o jej trwałości.

Analizowane przedstawienia malarskie powstały w znakomitej większości w czasach, kiedy nie rozwinęły się jeszcze badania krytyczne nad literaturą antyczną. Sprzyjało to oczywiście uogólnieniom, a nade wszystko egzageracji w prezentowaniu scen. $Z$ drugiej strony dzieła posiadają swoich konkretnych adresatów, którzy musieli być przygotowani do ich odbioru. Takie przygotowanie umożliwiało studiowanie dzieł literackich - szczególnie powszechne w epoce renesansu i oświecenia. Literatura antyczna, dając spójny i koherentny obraz bohatera - zdeterminowanego wroga Rzymu, wskazywała jednak na rys charakterologiczny ewidentnie wzbudzający szacunek. Hannibal bez wątpienia jest trudnym rywalem, obarczonym negatywnymi cechami ${ }^{121}$. Trzeba jednak zauważyć, że negatywne rysy charakterologiczne kartagińskiego dowódcy zostają w znacznej mierze przesłonięte przez jedną, którą stanowi determinacja. To w niej zawierają się inne: wiara w sens podejmowanych wysiłków, wytrwanie w podjętych decyzjach. Wydaje się zatem, że zainteresowanie determinacją pozwalało odnaleźć stosownego aktora w postaci historycznej, sprzyjając

121 Wytłumaczenia tych cech podjął się ostatnio Brizzi 2011, s. 483-498. 
jednocześnie tworzeniu ilustrowanych opowieści o zabarwieniu alegorycznym. Spojrzenie na europejskie zainteresowanie antykiem wskazuje, że była to epoka wyposażona $\mathrm{w}$ atrakcyjne z punktu widzenie kultury, rozległe instrumentarium symboliczne, przez co stanowiła nieoceniony rezerwuar środków wyrazu różnego rodzaju treści. Motywy antyczne można było wykorzystywać dowolnie w konceptualizacjach malarskich, co pozwalało uzyskiwać efekty znaczeniowe, koherentne z założeniami teocentrycznymi. Przykładem jest tutaj wywód wspomnianego już E. Tesauro, w którym podejmowana jest problematyka działania świętych wysłanników. Autor ten podkreśla, że zreferowane przez niego historie służyły wskazaniu bezrefleksyjności pogańskiego świata, w którym mianem Losu (Fato) i Przeznaczenia (Destino) nazywano to, co $\mathrm{w}$ istocie pochodziło od ducha ${ }^{122}$. Założenie to znajduje odzwierciedlenie $w$ uwzględnieniu postaci geniuszów wkomponowanych w treść części obrazów ${ }^{123}$. Oczywiście rozumienie symboliki wyrażonej na obrazach nie pozostawało bez związku z konkretną sytuacją polityczną. Co więcej, korelacja ta niejednokrotnie warunkowała sukces dzieła. Atrakcyjna w tym kontekście opowieść o dziejach Hannibala to w ogólnym rozrachunku historia bohatera, który ogniskuje w sobie przemiany historyczne, z drugiej zaś strony dostarcza atrakcyjnych motywów do tworzenia wyobrażeń religijnych. Pomimo że Liwiusz określa Hannibala jako wiarołomnego, ten jednak nigdy nie łamie danej bogom przysięgi - nigdy nie staje się przyjacielem Rzymian i do końca swoich dni działa na ich niekorzyść. Prezentacje malarskie eksponują tematy trudne, przeprawę przez Alpy, śmierć brata, przegraną bitwę pod Zamą, aby tym mocniej wskazać na niezłomność bohatera. Malarstwo inspirowało się antykiem w sposób nieoczywisty, wyszukując przykładów moralnych opierających się na wierności danemu słowu i religijnej przysiędze. Determinacja jawi się tutaj jako czynnik pierwszoplanowy, inspirujący i potrzebny Europie.

122 Tasauro 1682, s. 45.

123 Ważny powód artystów (m.in. J. Miela) do namalowania geniuszów wynikał z idei Tesauro, podług której sny, objawienia i wyrocznie były w istocie produktem odpowiedzi osobistego geniusza, który stale towarzyszy człowiekowi. W Il Cannochiale Aristotelico sytuuje on Cezara, który po tym, jak zobaczył giganta przekraczającego Rubikon, zrozumiał motto ducha swojego umysłu - „Idźmy tam, dokąd wzywają nas bogowie. Kości zostały rzucone" (tłum. M.W.). Te przyporządkowane Cezarowi słowa są w rzeczywistości translacją motta Alciatiego Qua dii vocant eundum. Por. Tesauro 1682, s. 44 : „Intese Cesare il motto dell'ingenoso suo Genio; e disse: Andianne la, ove gli Iddij ne chiamano Gittato e il dado (podkr. M.W.)"; Lammertse 1989, s. 256. 


\section{THE HISTORY OF HANNIBAL - ANCIENT LITERATURE VERSUS ARTISTIC REPRESENTATION}

\section{Summary}

The author of the article attempts to confront reports concerning the history of Hannibal found in classical literature with selected painterly representations created in later times, i.e. between the late Middle Ages/early Renaissance and the end of the $20^{\text {th }}$ century. This extensive issue, making up a part of a board range of problems classified as the reception of antiquity, requires making references to specific motifs from Hannibal's history. The author of the text focuses on an analysis of six motifs: an oath sworn by Hannibal upon the Carthaginian gods in his childhood, the dramatic march across the Alps, the exposed motif of an elephant, the personal drama of the Carthaginian commander who finds the severed head of his younger brother, Hasdrubal, the dramatic battle of Zama and finally, the scene of Hannibal's suicide. As a result of the analyses, the author concludes that painting was inspired by antiquity in a non-obvious manner, as it looked for moral examples based on faithfulness to a given word and religious oath. In those cases, Hannibal's determination and indomitableness provided the chief inspiration.

\section{Bibliografia}

Alciatti A. 1548, Emblemata, Lugduni.

Alcolea Blanch S. 1999, Aníbal, máscaras y anamorfosien del Cuaderno italiano de Goya, Barcelona. Aleksandrowicz J. 2012, Pomiędzy płótnem a ekranem: Inspiracje twórczością Goi w kinie hiszpańskim, Katowice.

Alt J.H. 2013, Don't Die in Bed. The Brief Intense Life of Richard Halliburton, Atlanta.

Bordes P. 2007, Jacques-Louis David: Empire to Exile, Yale University.

Bowen B.C. 1985, Mercury at the Crossroads in Renaissance Emblems, Journal of the Warburg and Courtauld Institutes 48, s. 222-229.

Breckenridge J. D. 1983, Hannibal as Alexander, Ancient World 7, s. 111-128.

Brizzi G. 1996, Maarbale e Annone di Bomilcare: riflessioni dal confronto tra due carriere, [w:] E. Acquaro (red.) Alle scoglie della classicità il Mediterraneo tra tradizione e innovazione. Studi in onore di Sabatino Moscati, I (Storia e Culturale), Pisa-Roma, s. 73-80.

Brizzi G. 2003, Lo scacchiere internazionale: Annibale e Filippo V, Hesperia, 17, s. 63-78.

Brizzi G. 2011, Carthage and Hannibal in Roman and Greek Memory, [w:] D. Hoyos (red.), A Companion to The Punic Wars, Blackwell, s. 483-498.

Butlin M., Joll E. 1977, The Paintings of J.M.W. Turner, New Haven-London.

Caltabiano M. 1975, La morte del console Marcello nella tradizione storiografica, Contributi dell'Istituto di Storia antica dell'Universita del Sacro Cuore. Vita\&Pensiero 3.

Christ K. 1974, Zur Beurteilung Hannibals, [w:] K. Christ (red.), Hannibal, Darmstadt, s. 361-407.

Chroust A.-H. 1974, Internationale Verträge in der Antike. Die diplomatischen Verhandlungen zwischen Hannibal und Philipp V von Makedonia, [w:] K. Christ (red.) Hannibal, Darmstadt 1974, s. 275-334.

Clark K. 1973, The Romantic Rebellion, New York.

D AArco I. 2002, Il sogno premonitore di Annibale e il pericolo delle Alpi, Quaderni di Storia, s. 145-162.

Devine M. 1975, Grand Tactics at Gaugamela, Phoenix, 29, s. 374-384. 
Domitilla Campanile M. 2000, Del bere sangue di toro e della morte di Annibale, Chiron, 30, s. 123-128. Dover K.J. 1978, Greek Homosexuality, London.

Eckstein A.M. 2005, The Pact Between The Kings, Polybius 15.20.6, and Polybius' View of the Outbreak of the Second Macedonian War, Classical Philology, 100, s. 228-242.

Ernout A. 1952, Pline l'ancien. Histoire naturelle (Livre VIII), texte établi, traduit et commenté par A. Ernout.

Faber M.D. 1967, Suicide and the Ajax of Sophocles, Psychoanalytic Review 54, s. 441-452.

Finberg A. 1909, Complete Inventory of the Drawings of the Turner Bequest, London.

Finberg A. 1961, The Life of J.M.W. Turner, London.

Gage J. 1969, Colour in Turner: Poetry and Truth, London.

Geus K., Prosopographie der literarisch bezeugten Karthagern, Leuven.

Grimal P. 1987, Słownik mitologii greckiej i rzymskiej, Wrocław.

Grise Y. 1982, La suicide dans la Rome antique, Paris.

Günther L.M. 1989, Hannibal im Exil: seine antirömische und die römische Gegenwahrnehmung, [w:] H. Devijver, E. Lipiński (red.), Proceedings of the Conference held in Antwerp from $23^{\text {th }}$ to $26^{\text {th }}$ of November 1988 in cooperation with the Department of History of the 'Universiteit Antwerpen' (U.F.S.I.A.), Leuven, s. 241-250.

Günther M. L. 2010, Hannibal. Ein biographisches Porträt, Freibourg-Wien.

Hammond N.G.L. 2008, The Expedition of Datis and Artaphernes, The Cambridge Ancient History, 4, Cambridge, s. 491-517.

Hampl F. 1983-1984, Probleme der Forschung zum Hannibalischen Krieg im alter und neuer Sicht, Rivista Storica dell'Antichità, 13-14, s. 9-29.

Händl-Sagawe U. 1995, Der Beginn des 2. punischen Krieges. Ein historisch-kritischer Kommentar zu Livius Buch 21, München.

Halkin L. 1934, Hannibal ad portas!, Les Études Classiques, 3, s. 454-457.

Hart J. 1982, Herodotus and Greek History, New York.

Hoffmann W. 1961, Hannibal, Göttingen.

Holowchak M. A. 2002, Ancient Science and Dreams. Oneirology in Greco-Roman Antiquity, Oxford.

Hopfner Th. 1937, Traumdeutung, Real-encyclopädie der classischen Altertumswissenschaft, 12, kol. 2233-2245.

Hoyos D. 2000, Maharbal's Bon Mot: Authenticity and Survival, Classical Quarterly, 50, s. 610-614.

Hoyos D. 2003, Hannibal's Dynasty. Power and politics in the western Mediterranean 247-183 BC, London-New York.

Hoyos D. 2008, Hannibal Rome's Greatest Enemy, Bristol.

Hughes R. 2006, Goya. Artysta i jego czas, Warszawa.

Kren T. 1978, Jan Miel (1599-1664), a Flemish painter in Rome, Yale (diss.).

Kühnen A. 2008, Die «Imitatio Alexandri» in der römischen Politik (1. Jh. V. Chr - 3. Jh. N. Chr.), Münster.

Lammertse F. 1989, Hannibal's Dream. A Painting by Jan Miel after an Idea by Emanule Tesauro, Journal of the Warburg and Courtauld Institutes 52, s. 253-256.

Lancel S. 2001, Hannibal, Warszawa.

Larson F. 2017, Historia świata przez ścięte głowy opisana, Warszawa.

Laudizi G. 1989, Silio Italico. Il passato fra mito e restaurazione etica, Gelatina.

Levene D.S. 2012, Livy on the Hannibalic War, Oxford. 
Loreto L. 2007, La Grande Strategia di Roma nell'Età della Prima Guerra Punica (ca. 273-ca. 229 a.C.): L'inizio di un paradosso, Napoli.

Loreto L. 2011, Roman Politics and Expansion, 241-218, [w:] D. Hoyos (red.), A Companion to The Punic Wars, Blackwell, s. 184-203.

MacDonald E. 2015, Hannibal a Hellenistic Life, London.

Marks R. 2008, Getting Ahead: Decapitation a Political Metaphor in Silius Italicus' Punica, Mnemosyne, 61, s. 66-88.

Mathieu J. 2015, A dos déléphant à travers les Alpes en l'an 1935 après J.C.: sur la réception d'Hannibal à lépoque contemporaine, Vallesia, 70, s. 139-149.

Matteson L. R. 1989, The Poetics and Politics of Alpine Passage - Turner's Snowstorm - Hannibal and His Army Crossing the Alps, The Art Bulletin 97, s. 385-398.

Matusiak P. 2015, Obraz Hannibala w literaturze antycznej, Katowice.

Matusiak P. 2017, Cannas pensavimus, czyli Syliusz Italik o głowie Hazdrubala (Sil. Pun. 15.809823), Scripta Classica, 14, s. 29-35.

Mayor A.H. 1955, Hannibal Crossing the Alps, The Burlington Magazine, 97, s. 296.

Michaud C. 2006, Johan Heinrich Schönfeld. Un Peinte Allemand du XVIIe Siecle en Italie, Monaco.

Miles R. 2010, Carthage Must be Destroyed. The Rise and Fall of an Ancient Mediterranean Civilization, Allen Lane.

Miles R. 2011, Hannibal and Propaganda, [w:] D. Hoyos (red.), A Companion to The Punic Wars, Blackwell, s. 260-279.

Mineo B. 1994, La philosophie de la communication entre dirigeants et dirigés dans l’Ab Urbe Condita de Tite-Live, Lille.

Morta K. 2004, Świat egzotycznych zwierząt u Solinusa, Wrocław.

Muecke F. 2010, Silius Italicus in the Italian Renaissance, [w:] A. Augoustakis (red.), Brills Companion to Silius Italicus, Leiden, s. 401-424.

Näf B. 2000, Antyczna interpretacja snów, Poznań.

Nicolson M. 1959, Mountain Gloom, Mountain Glory, Ithaca.

Oehler R. 1897, Der letzte Feldzug des Barkiden Hasdrubal und die Schlacht am Metaurus, Berlin.

Pearson L. 1975, The Virtuoso Passages in Demosthenes' Speeches, Phoenix 29, s. 214-230.

Peter H. 1911, Wahrheit und Kunst Geschichtsschreibung und Plagiat im klassichen Altertum, Leipzig-Berlin.

Rink E. 1933, Die bildlichen Darstellunen des römisches Genius, Berlin.

Ripa C. 1603, Iconologia, Rome = Ripa C. 1970, Iconologia, Hildesheim.

Rostropowicz J. 2002, Królowie i charytki. Poeci na hellenistycznych dworach, Opole.

Rovere C. 1858, Descrizione del Reale Palazzo di Torino, Turyn.

Sánchez Cantón F. J. 1931, La estancia de Goya en Italia, Archivo Espanol de Arte 7, 1931, s. 182-184 Schneider Th. 2001, Leksykon Faraonów, Warszawa-Kraków.

Schnapp A. 1997, Le Chasseur et la cité: chasse et érotique en Grece ancienne, Paris.

Schoch R. 1975, Das Herrscherbild in der Malerei des 19. Jahrhunderts, München.

Schubert Ch. 2011, Der Traum des Hipparch. Fiktionalität und Ereignis bei Herodot, Musem Helveticum 68, 2011, s. 1-20.

Scullard H.H. 1974, The Elephant in the Greek and Roman World, London.

Siebenmorgen H., Hattler C., Krause B. 2005, Karthago - eine Erinnerung, [w:] Badischen Landesmuseum Karlsruhe (red.), Hannibal ad portas. Macht und Reichtum Karthagos, Karlsruhe, s. $362-379$. 
Sommella A.M., Tittoni Monti M.E. 1996, Meisterwerke der Kapitolinischen Museen, Roma.

Stanzel F. 1964, Das Bild der Alpen in der englischen Literatur des 17. und 18. Jhdts., Germanisch-romanische Monatschrift 14, s. 121-138.

Tesauro E. 1682, Il Cannochiale Aristotelico, Venice.

Thalheim F. 1921, Selbstmord, Real-encyclopädie der classischen Altertumswissenschaft, kol. 11341135.

Urrea J. 1993, Goya en Italia. A propósito del Aníbal Boletin del Museo del Prado 14/32, 1993, s. 5963.

Vinchesi M. A. 2004, Introduzione, traduzione e note, [w:] M. A. Vinchesi (red.), Silio Italico, Le Guerre Puniche, I, Milano, s. 5-77.

Vitek T. 2017, Allegorical Dreams in Antiquity. Their Charakter and Interpretation, Wiener Studien 130 , s. $127-152$

Weber G. 2000, Kaiser, Träume und Visionen in Prinzipat und Spätantike, Stuttgart.

Wilton A. 1979, J. M. W. Turner. Leben und Werk, Freiburg.

Wolny M. 2005, Hannibal's Oath before Expedition to Gades (237 BC) - Functions and Way of Reception, Antiquitas 27, s. 27-31.

Wolny M. 2007, Hannibal w Italii (218-217 p.n.e.). Studia nad uwarunkowaniami początkowych sukcesów kartagińskich, Olsztyn.

Wolny M. 2015, Hannibal jako twórca sfałszowanej korespondencji? List do mieszkańców Salapii (208 p.n.e.), Echa Przeszłości 16, s. 7-23.

Wolny M. 2016, Studia nad satusem i kompetencjami dowódców kartagińskich w okresie przewagi Barkidów (237-201 p.n.e.), Oświęcim.

Wolny M. 2017, Przemoc polityczna w Kartaginie po roku 201 p.n.e. a okoliczności ucieczki Hannibala, [w:] D. Słapek, I. Łuć (red.), Przemoc w świecie starożytnym: źródła - struktura - interpretacje, Lublin, s. 171-188.

Wolny M. 2020, Recepcja antycznej symboliki Snu Hannibala na przykładzie dzieła malarskiego Jana Miela „Il sonno di Annibale fra gl'Iberi” (w przygotowaniu).

Wooten C. 1974, The Speeches in Polybius: An Insight into the Nature of Hellenistic Oratory, American Journal of Philology 95, s. 235-251.

Zimmermann K. 2008, Hannibal ante portas: Warum verzichtete Hannibal 216 v. Chr. auf den Marsch auf Rom?, [w:] K. Brodersen (red.), Vincere Scis, Victoria Uti Nescis. Aspekte der Ruckschauverzerrung in der Alten Geschichte, Berlin, s. 49-60.

Ziółkowski A. 1993, Urbs direpta, or how the Romans sacked cities, [w:] J. Rich, G. Shipley (red.), War and Society in The Roman World, London, s. 69-90. 